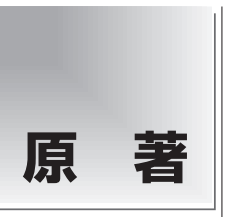

論文受付

2017 年 4 月 14 日

論文受理

2017 年 9 月 22 日

Code No. 261

\section{撮像パラメータが Synthetic MRI に及ぼす影響について}

\author{
今田奈津夫 ${ }^{1}$ 渋川周平 ${ }^{1}$ 白鳥智章 ${ }^{1}$ 堀江朋彦 ${ }^{1}$ 小原 真 $^{2}$ \\ ${ }^{1}$ 東海大学医学部付属病院診療技術部放射線技術科 \\ 2フィリップスエレクトロニクスジャパンヘルスケア
}

\section{緒 言}

Magnetic resonance imaging(MRI) は組織それぞれ がもつプロトンやそのスピンの緩和の違いを画像化し ており，その高いコントラストから現在の臨床におい て必要不可欠なモダリティの一つである. MRI は撮 像前に設定したパラメータに応じたコントラストの画 像が得られる，実際の臨床現場では，診断に複数の異 なるコントラスト画像を必要としており, 数回の撮像 を繰り返すため長い検査時間を要している.

一方, synthetic MRI は一度の撮像で各ピクセル単 位の proton density $(\mathrm{PD}), \mathrm{T}_{1}$ 值, $\mathrm{T}_{2}$ 值を求められ, 得 られた定量值より任意のコントラスト画像をポストプ ロセスで作成できる画期的な技術である。既に Sturge Weber 症候群 ${ }^{1,2)}$ や転移性脳腫瘍 ${ }^{3)}$ での有用性 も報告されており，MRIの新しい技術として期待され ている.
しかし，その撮像パラメータを変化させた際に $\mathrm{T}_{1}$. $\mathrm{T}_{2}$ 值算出にどのような影響を与えるかについての詳 細な報告はまだない，今回われわれはSyMRI のアプ リケーションを導入した 3.0 T MR 装置を使用する環 境を得た。そこで synthetic MRIに㧍ける撮像パラ メータが $\mathrm{T}_{1} \cdot \mathrm{T}_{2}$ 值算出へ及ぼす影響を自作ファント ムとボランティアにより検証したので報告する。

\section{1. 理 論}

以前より $\mathrm{T}_{1} \cdot \mathrm{T}_{2}$ 值を同時計測する手法として mixed シーケンスを用いた手法は報告されていたが, その撮像時間の長さから臨床応用には向かなかっ

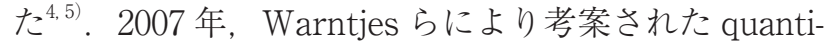
fication of relaxation times and proton density by twinecho saturation-recovery turbo-field echo (QRAPTEST) 法は saturation pulse を使用することで

\title{
The Effect of Scan Parameters on the Synthetic MRI
}

\author{
Natsuo Konta, ${ }^{1 *}$ Syuhei Shibukawa, ${ }^{1}$ Tomoaki Hakucho, ${ }^{1}$ Tomohiko Horie, ${ }^{1}$ and Makoto Obara ${ }^{2}$ \\ ${ }^{1}$ Department of Radiology, Tokai University Hospital \\ ${ }^{2}$ Healthcare Department, Philips Electronics Japan
}

Received April 14, 2017; Revision accepted September 22, 2017

Code No. 261

\section{Summary}

Synthetic MRI can provide proton density (PD), $\mathrm{T}_{1}$ value, $\mathrm{T}_{2}$ value for each pixel by only one data acquisition and can create various contrast-weighted images. The aim of this study is to evaluate the effect on the calculation of the $\mathrm{T}_{1} \cdot \mathrm{T}_{2}$ value when changing the scan parameters for synthetic MRI. In the phantom study, when changing $1 \mathrm{st}$ TE/2nd TE/TR/TSE factor, the effect on the $\mathrm{T}_{1} \cdot \mathrm{T}_{2}$ value calculated by synthetic MRI was examined. In the volunteer study, the brain was imaged and compared with known $\mathrm{T}_{1} \cdot \mathrm{T}_{2}$ value. In phantom study, the effect on the $\mathrm{T}_{2}$ value by the $1 \mathrm{st}$ TE/2nd TE/TSE factor was shown. In volunteer study, there was no problem in the calculated value of brain parenchyma. However, the $T_{2}$ value of cerebrospinal fluid had the error of known value. The results show that it is necessary to set appropriate scan parameters on synthetic MRI.

Key words: synthetic MRI, 3.0 T, $\mathrm{T}_{1}$ value, $\mathrm{T}_{2}$ value

*Proceeding author 
$\mathrm{T}_{1} \cdot \mathrm{T}_{2}{ }^{*}$ 值の同時計測の高速化を可能にした ${ }^{6)}$. また, 2008 年には QRAPTEST 法を改良し, spin echo 法, お よび multi-slice 法を使用した quantification of relaxation times and proton density by multi-echo acquisition of a saturation-recovery using turbo spin echo readout (QRAPMASTER) 法が考案され, $\mathrm{T}_{1} \cdot \mathrm{T}_{2}$ 值を臨床応 用可能な時間内で得ることが可能となった ${ }^{77}$.

Synthetic MRI には, この QRAPMASTER パルス シーケンスが使用され multi-delay, multi-echo 収集に より, 各スライスで 4 種類の saturation delays, 2 種 類の echo time (TE)の 8 種類のデー夕収集をしてい る. そして，4 種類の saturation delays の画像から $\mathrm{T}_{1}$ 緩和曲線を推定し, ピクセル毎に $\mathrm{T}_{1}$ 值, $\mathrm{PD}$ を算出す る. 同様に 2 種類の $\mathrm{TE}$ の画像からピクセル毎に $\mathrm{T}_{2}$ 值を算出し，これらの結果から任意のコントラスト画 像をポストプロセスで作成している7).

\section{2. 方 法}

\section{2-1 使用装置および対象}

\section{2-1-1 使用装置}

MR 装置は PHILIPS 社製 Ingenia $3.0 \mathrm{~T}$ ，受信コイ ルはファントム実験に sensitivity encoding parallel imaging(SENSE) knee coil (8ch), ボランティア撮像に dS head spine coil (15ch)を使用した. Synthetic MRI のアプリケーションはSyMRI(Synthetic MR 社)を用 いた。

\section{2-1-2 対象}

a) 測定用試料として olive oil, baby oil，ガドリニウ 厶 $(\mathrm{Gd})$ 水溶液 $(0.1,0.4,0.8 \mathrm{mmol} / \mathrm{l})$, 塩化マンガン $\left(\mathrm{MnCl}_{2}\right)$ 水溶液 $(0.016,0.032 \mathrm{~g} / \mathrm{l})$ を用意し, 直径 2.5 $\mathrm{cm}$ のアクリル円柱容器に密閉した。 上記 7 個の試料 を更に別のプラスチック容器 $(12 \times 12 \times 30 \mathrm{~cm})$ に入れ, その周りを蒸留水に廃液凝固剂 FF350 (大研医器株式 会社)を混ぜたもので固め, 試料の容器を固定した(自 作ファントム)。自作ファントムと SENSE knee coil の位置関係を Fig. 1 に示す.

なお，温度変化による影響を考慮し，ファントムを 24 時間マグネット中心部に設置し, 室温 $\left(24^{\circ} \mathrm{C}\right)$ で実験 を行った。

b) ボランティアは当院の倫理委員会による承認と, 本検討の趣旨を十分に説明し, 自由意志に基づいて同 意を得た健常ボランティア 17 名 (男性 9 名, 女性 8 名, 22〜30 歳 [平均年齢 23.4 歳, 既往歴はない]) を対 象とした。

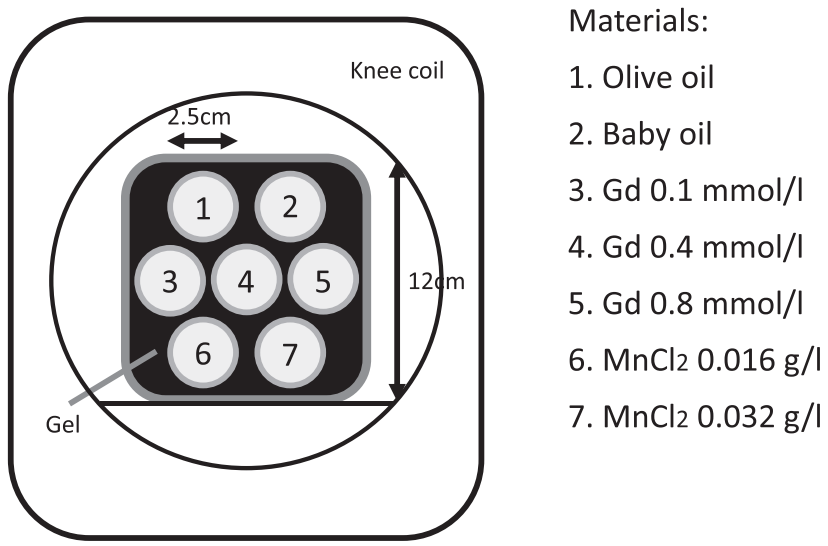

Fig. 1 Materials and position of the phantom image and physical relationship of the phantom.

\section{2-2 検討方法}

\section{2-2-1ファントムによる検討}

a) 撮像パラメータが synthetic MRI に及ぼす影響の 検討

指標としての $\mathrm{T}_{1}$ 值算出に inversion recovery (IR) 法を用いて inversion time(TI)を50，100，200，400， 700, 1000, 1500, 2000, 3000, 3500, 4000, $5000 \mathrm{~ms}$ まで変化させ自作ファントムを撮像した。

同様に $\mathrm{T}_{2}$ 值算出には multi-echo 法を用い TE を 20，40，60，80，100，120，140，160，180，200 ms ま で変化させた。 なお, PHILIPS 社製 MR 装置では $\mathrm{T}_{2}$ 值測定は multi-echoによる手法のみである。装置上， TE を等間隔に 10 枚までの画像作成が限界であった ため, 本検討では実臨床を考慮し, 脳実質に合わせた TE を設定した，以下，IR 法拉よび multi-echo 法を従 来法と定義する。従来法の撮像条件を Table 1 に示 す。従来法では基準となる真值を求めるために十分な スライス厚とした。

一方, synthetic MRI ではコントラストに起因する パラメータである1st TE, 2nd TE, repetition time (TR), turbo spin-echo(TSE)factor をそれぞれ変化さ せ自作ファントムを撮像し, $\mathrm{T}_{1} \cdot \mathrm{T}_{2}$ 值を求めた。 PHILIPS 推奨条件を参考にし, 基準となる撮像条件を 決定した(Table 2)，パラメータはそれぞれ 1st TE： 5, 10, $20[\mathrm{~ms}], 2$ nd TE : 100, 150, 200 [ms], TR : 1200, 3500, 4500 [ms], TSE factor : 6, 10, 18 と変化 させた. Synthetic MRIでは実臨床を考慮し頭部領域 を想定したスライス厚とした。

なお，関心領域(region of interest: ROI) は自作ファ ントムの各試料に $11 \times 11 \mathrm{~mm}$ とした.

\section{2-2-2 ボランティアによる検討}

Synthetic MRI を使用し, 健常ボランティア 17 名の 
Table 1 Pulse sequence parameter for measurement $T_{1}$ and $T_{2}$ value

\begin{tabular}{lcc}
\hline \hline & For measurement $\mathrm{T}_{1}$ value & For measurement $\mathrm{T}_{2}$ value \\
\hline Scan mode & 2D Inversion recovery & 2D Multi spin echo \\
TR [ms] & 10000 & 4000 \\
TE [ms] & 15 & $20,40,60,80,100$, \\
& & $120,140,160,180,200$ \\
TI [ms] & $50,100,200,400,700,1000,1500$, & No \\
& $2000,3000,3500,4000,5000$ & 10 \\
TSE factor & No & 10 \\
Echoes & 1 & 176 \\
Matrix & 208 & 250 \\
FOV [mm] & 250 & 100 \\
RFOV [\%] & 100 & 2.5 \\
SENSE factor & No & 5 \\
Slice thickness [mm] & 10 & 434.4 \\
Band width [Hz/pixel] & 435.5 & \\
\hline
\end{tabular}

Table 2 Synthetic MRI scan parameters

\begin{tabular}{|c|c|c|c|c|c|c|c|}
\hline \multicolumn{4}{|c|}{ Phantom study } & \multicolumn{4}{|c|}{ Volunteer study } \\
\hline Scan mode & $\begin{array}{l}\text { Multi delay } \\
\text { Multi echo }\end{array}$ & & & Scan mode & $\begin{array}{l}\text { Multi delay } \\
\text { Multi echo }\end{array}$ & & \\
\hline $\mathrm{TR}[\mathrm{ms}]$ & 4500 & Matrix & 336 & $\mathrm{TR}[\mathrm{ms}]$ & 4266 & Matrix & 328 \\
\hline $1 \mathrm{st} \mathrm{TE}[\mathrm{ms}]$ & 5 & $\mathrm{FOV}[\mathrm{mm}]$ & 250 & $1 \mathrm{st} \mathrm{TE}[\mathrm{ms}]$ & 13 & $\mathrm{FOV}[\mathrm{mm}]$ & 230 \\
\hline 2nd TE $[\mathrm{ms}]$ & 100 & RFOV [\%] & 100 & 2nd TE [ms] & 100 & RFOV $[\%]$ & 82.93 \\
\hline Act TE $[\mathrm{ms}]$ & $13 / 100$ & SENSE factor & 2 & Act TE $[\mathrm{ms}]$ & $13 / 100$ & SENSE factor & 2.2 \\
\hline TSE factor & 10 & Half scan & No & TSE factor & 10 & Half scan & No \\
\hline Echoes & 2 & Scan percentage $[\%]$ & 77.4 & Echoes & 2 & Scan percentage $[\%]$ & 80.6 \\
\hline Echo space $[\mathrm{ms}]$ & 12.5 & Slice thickness $[\mathrm{mm}]$ & 4 & Echo space $[\mathrm{ms}]$ & 12.5 & Slice thickness $[\mathrm{mm}]$ & 4 \\
\hline Flip angle $\left[{ }^{\circ}\right]$ & 90 & Band width [Hz/pixel $]$ & 217.6 & Flip angle $\left[{ }^{\circ}\right]$ & 90 & Band width [Hz/pixel] & 208.2 \\
\hline \multicolumn{2}{|c|}{ Scan time (min) } & $7: 57$ & & \multicolumn{2}{|c|}{ Scan time (min) } & $5: 50$ & \\
\hline
\end{tabular}

頭部 axial を撮像した，撮像条件はファントム検討時 と同様に PHILIPS 推奨条件を参考にし，基準となる 撮像条件を決定した。 それぞれ白質, 灰白質, 脳脊髄液 に正方形 $5 \times 5 \mathrm{~mm}$ の ROI を設定し(Fig. 2)， $\mathrm{T}_{1} \cdot \mathrm{T}_{2}$ 值 の測定を行った。撮像条件を Table 2 に示す。

\section{3. 結 果}

\section{3-1 従来法との $T_{1} \cdot T_{2}$ 值の比較}

IR 法より算出した各試料の $\mathrm{T}_{1}$ 值は $297.4 \mathrm{~ms}$ (olive oil), $304.4 \mathrm{~ms}$ (baby oil), Gd 水溶液 (0.1, $0.4,0.8$ mmol/l) はそれぞれ $1023.9 \mathrm{~ms}, 434.7 \mathrm{~ms}, 334 \mathrm{~ms}$, $\mathrm{MnCl}_{2}$ 水溶液 $(0.016,0.032 \mathrm{~g} / 1)$ はそれぞれ $843.6 \mathrm{~ms}$, 518.6 ms であった。

Multi-echo 法より算出した各試料の $\mathrm{T}_{2}$ 值は 104.8 ms (olive oil), $100.9 \mathrm{~ms}$ (baby oil), Gd 水溶液 (0.1, 0.4, $0.8 \mathrm{mmol} / \mathrm{l})$ はそれぞれ $753 \mathrm{~ms}, 394.1 \mathrm{~ms}, 225.2 \mathrm{~ms}$, $\mathrm{MnCl}_{2}$ 水溶液 $(0.016,0.032 \mathrm{~g} / 1)$ はそれぞれ $88.5 \mathrm{~ms}$, $47.1 \mathrm{~ms}$ であった。

以上の従来法による測定値と Table 2 の撮像条件よ り synthetic MRI で測定した各試料の $\mathrm{T}_{1} \cdot \mathrm{T}_{2}$ 值との

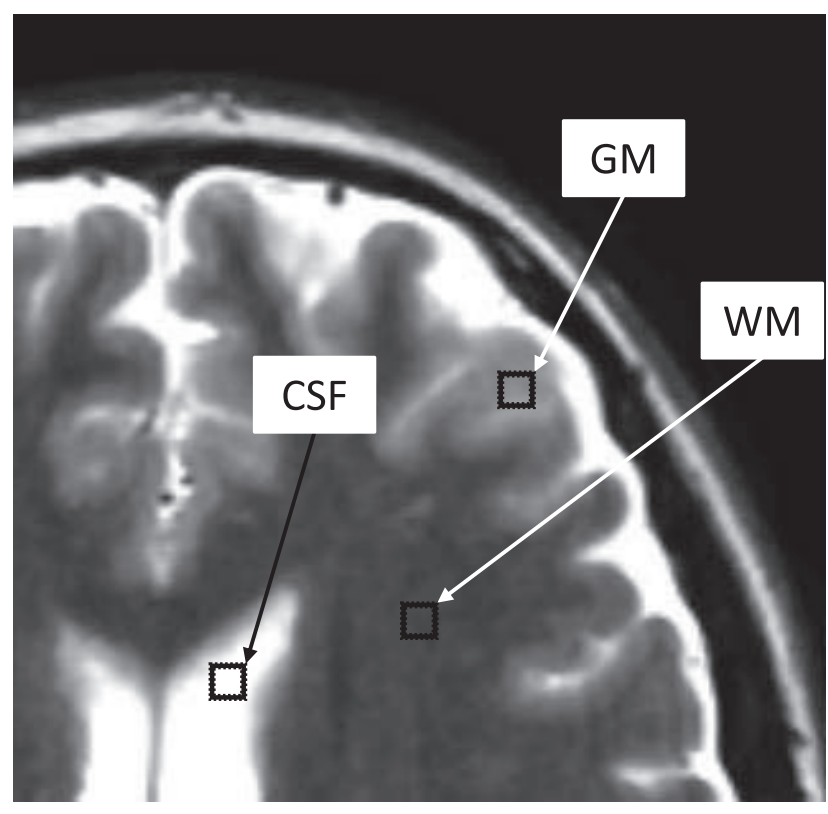

Fig. 2 Clinical image and position of region of interest (ROI) for measurement $T_{1}$ and $T_{2}$ value. ROI size: $5 \times 5 \mathrm{~mm}$

WM: white matter, GM: gray matter, CSF: cerebrospinal fluid

The $T_{1}$ and $T_{2}$ value are measured by setting ROI on synthetic MRI. 

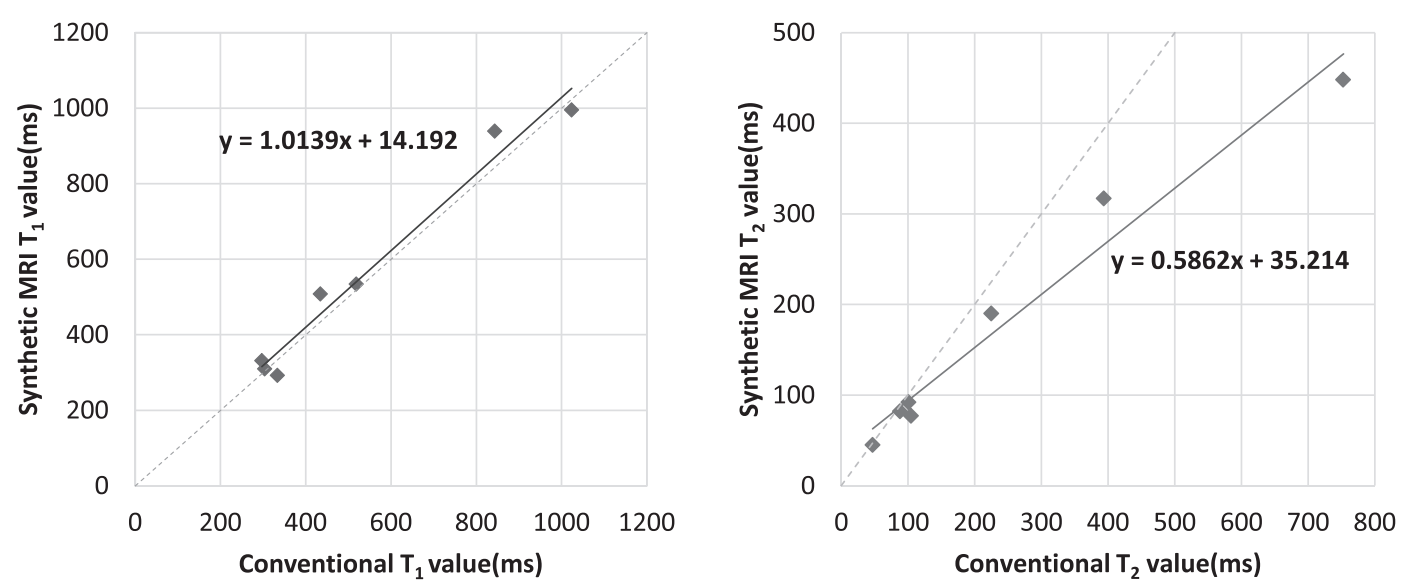

Fig. 3 Correlation diagram between conventional measurement $T_{1}$ and $T_{2}$ value and synthetic MRI. The dotted line is a correlation function. The continuous line is a function of this study.

(a) Correlation diagram of $T_{1}$ value. There is a correlation between them.

(b) Correlation diagram of $T_{2}$ value. $T_{2}$ value that is calculated by synthetic MRI is underestimated.

関係を Fig. 3 に示す.相関グラフより, $T_{1}$ 值は正の相 関関係であった。 $\mathrm{T}_{2}$ 值では synthetic MRI の測定值 は従来法と比較し過小評価されている結果となった.

\section{3-2 撮像パラメータを変化させた際の $\mathrm{T}_{1} ・ \mathrm{~T}_{2}$ 值への 影響}

\section{3-2-1 1st TE を変化させた場合}

1st TE : 5 の olive oil, baby oil, Gd $0.1 \mathrm{mmol} / \mathrm{l}$, Gd $0.4 \mathrm{mmol} / \mathrm{l}, \quad$ Gd $0.8 \mathrm{mmol} / \mathrm{l}, \quad \mathrm{MnCl}_{2} 0.016 \mathrm{~g} / \mathrm{l}, \quad \mathrm{MnCl}_{2}$ $0.032 \mathrm{~g} / 1$ の $\mathrm{T}_{1}$ 值はそれぞれ 331，309，995，508，292, 939, $534 \mathrm{~ms}$ で, この值を基準值として 1st TE を変化 させた際の $\mathrm{T}_{1}$ 值変化率は最大で $4.2 \%$ あっった。した がって， $\mathrm{T}_{1}$ 值に大きな差はみられなかった。同様に 1st TE : 5 の olive oil, baby oil, Gd 0.1 mmol/l, Gd 0.4 $\mathrm{mmol} / \mathrm{l}, \quad$ Gd $0.8 \mathrm{mmol} / \mathrm{l}, \quad \mathrm{MnCl}_{2} 0.016 \mathrm{~g} / \mathrm{l}, \quad \mathrm{MnCl}_{2} 0.032$ $\mathrm{g} / 1$ の $\mathrm{T}_{2}$ 值はそれぞれ $77 ， 92 ， 448 ， 317 ， 190 ， 82 ， 45$ msで, この值を基準值とした。すると, baby oil と $\mathrm{Gd}$ 水溶液 $(0.1 \mathrm{mmol} / \mathrm{l}, 0.4 \mathrm{mmol} / \mathrm{l})$ の試料において $12.0 \%$ 以上の変動がみられた。

\section{3-2-2 2nd TE を変化させた場合}

2nd TE : 100 の olive oil, baby oil, Gd $0.1 \mathrm{mmol} / \mathrm{l}$, Gd $0.4 \mathrm{mmol} / \mathrm{l}$, Gd $0.8 \mathrm{mmol} / 1, \mathrm{MnCl}_{2} 0.016 \mathrm{~g} / \mathrm{l}$, $\mathrm{MnCl}_{2} 0.032 \mathrm{~g} / 1$ の $\mathrm{T}_{1}$ 值はそれぞれ 331，309，995， 508,292, 939, $534 \mathrm{~ms}$ で, この值を基準值として 2nd

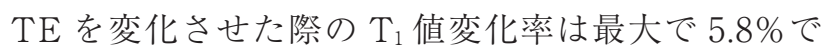
あった。したがって， $\mathrm{T}_{1}$ 值に大きな差はみられな かった，同様に2nd TE：100 の olive oil, baby oil, Gd $0.1 \mathrm{mmol} / \mathrm{l}$, Gd $0.4 \mathrm{mmol} / \mathrm{l}$, Gd $0.8 \mathrm{mmol} / \mathrm{l}, \mathrm{MnCl}_{2}$ $0.016 \mathrm{~g} / \mathrm{l}, \mathrm{MnCl}_{2} 0.032 \mathrm{~g} / \mathrm{l}$ の $\mathrm{T}_{2}$ 值はそれぞれ 77, 92, 448，317，190，82，45 ms で，この值を基準值とした.
すると, olive oil, baby oil, Gd 水溶液 $(0.1 \mathrm{mmol} / \mathrm{l})$ の 試料において 10.4\%以上の変動がみられた。

\section{3-2-3 TR を変化させた場合}

TR : 2700 の olive oil, baby oil, Gd $0.1 \mathrm{mmol} / \mathrm{l}, \mathrm{Gd}$ $0.4 \mathrm{mmol} / \mathrm{l}$, Gd $0.8 \mathrm{mmol} / \mathrm{l}, \quad \mathrm{MnCl}_{2} 0.016 \mathrm{~g} / \mathrm{l}, \quad \mathrm{MnCl}_{2}$ $0.032 \mathrm{~g} / 1$ の $\mathrm{T}_{1}$ 值はそれぞれ $318 ， 290 ， 1007 ， 517$, 288，944，537 ms で，この值を基準值として TR を変 化させた際の $\mathrm{T}_{1}$ 值変化率は最大で $6.6 \%$ であった，し たがって， $\mathrm{T}_{1}$ 值に大きな差はみられなかった。同様 に TR : 2700 の olive oil, baby oil, Gd $0.1 \mathrm{mmol} / \mathrm{l}, \mathrm{Gd}$ $0.4 \mathrm{mmol} / \mathrm{l}$, Gd $0.8 \mathrm{mmol} / \mathrm{l}, \quad \mathrm{MnCl}_{2} 0.016 \mathrm{~g} / \mathrm{l}, \mathrm{MnCl}_{2}$ $0.032 \mathrm{~g} / 1$ の $\mathrm{T}_{2}$ 值はそれぞれ $77 ， 92 ， 443 ， 314 ， 189$, 83，45 msで，この值を基準值として TR を変化させ

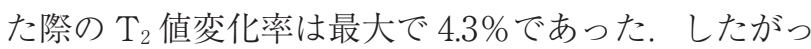
て， $\mathrm{T}_{2}$ 值にも大きな差はみられなかった。

\section{3-2-4 TSE factor を変化させた場合}

TSE factor : 6 の olive oil, baby oil, Gd $0.1 \mathrm{mmol} / \mathrm{l}$, Gd $0.4 \mathrm{mmol} / 1$, Gd $0.8 \mathrm{mmol} / 1, \mathrm{MnCl}_{2} 0.016 \mathrm{~g} / \mathrm{l}$, $\mathrm{MnCl}_{2} 0.032 \mathrm{~g} / 1$ の $\mathrm{T}_{1}$ 值はそれぞれ 346，324，1005， 515，288，953，547 msで，この值を基準值として TSE factor を変化させた際の $\mathrm{T}_{1}$ 值変化率は最大で 7.6\%であった。したがって， $\mathrm{T}_{1}$ 值に大きな差はみら れなかった。同様に TSE factor : 6 の olive oil, baby oil, Gd $0.1 \mathrm{mmol} / \mathrm{l}$, Gd $0.4 \mathrm{mmol} / \mathrm{l}$, Gd $0.8 \mathrm{mmol} / \mathrm{l}$, $\mathrm{MnCl}_{2} 0.016 \mathrm{~g} / \mathrm{l}, \mathrm{MnCl}_{2} 0.032 \mathrm{~g} / 1$ の $\mathrm{T}_{2}$ 值はそれぞれ 76，74，437，301，172，61，45 msで，この值を基準 值とした，すると，TSE factor：10 ではすべての試料 で 10.6\%以上の変動がみられた．更に TSE factor：18 ではすべての試料で 20.3\%以上の大幅な変動がみられ た. TSE factor 数を増やすほど $\mathrm{T}_{2}$ 值は高值となる傾 


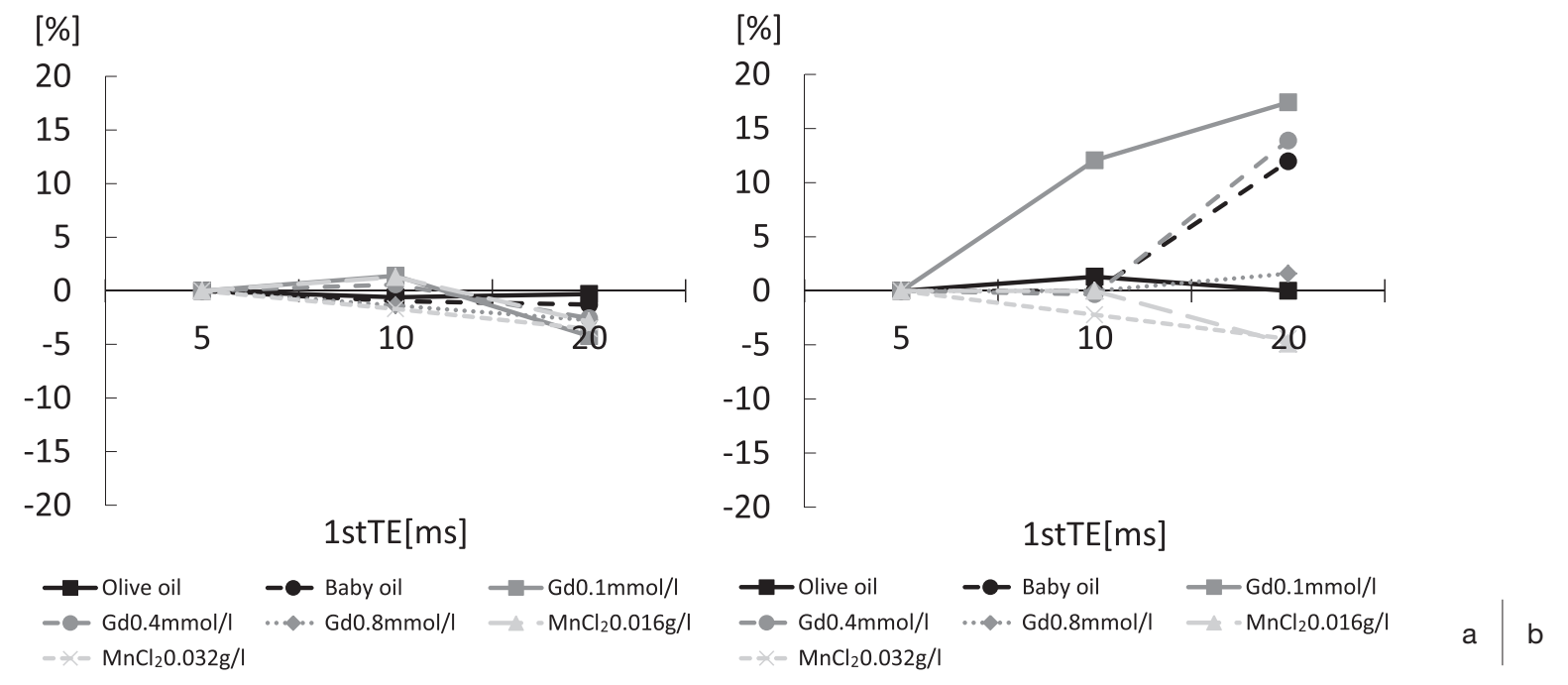

Fig. 4 The rate of change for $T_{1} \cdot T_{2}$ value by changing the 1 st TE.

(a) The rate of change for $T_{1}$ value

(b) The rate of change for $T_{2}$ value
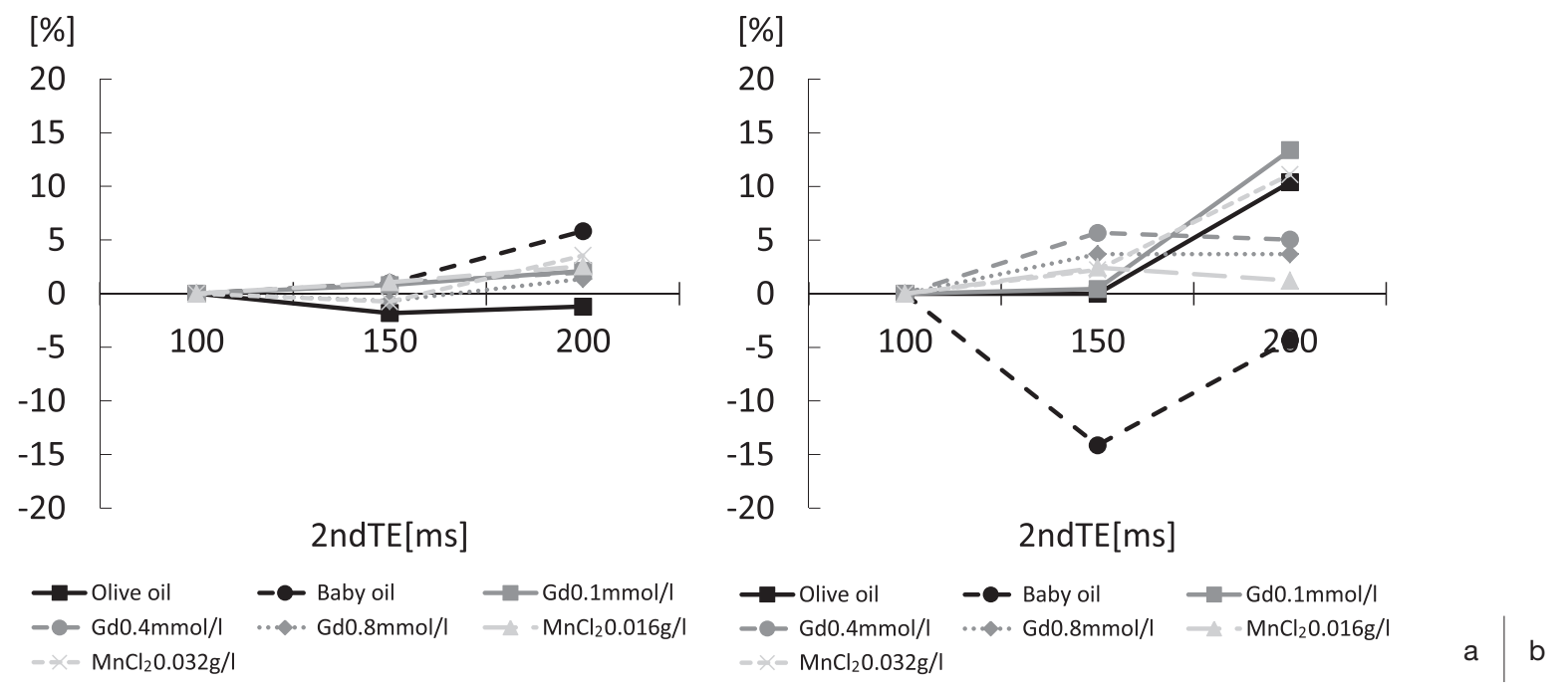

Fig. 5 The rate of change for $T_{1} \cdot T_{2}$ value by changing the 2 nd TE.

(a) The rate of change for $T_{1}$ value

(b) The rate of change for $T_{2}$ value

向があった。

以上の測定結果を Fig. 4〜 に示す。また，これら の撮像パラメータを変化させた際に act TE(実効 TE) の範囲が設定した TE と異なることがあった。

\section{3-3 ボランティアの $\mathrm{T}_{1} \cdot \mathrm{T}_{2}$ 值}

健常ボランティア 17 名の頭部各組織の測定平均值 と標準偏差を Fig. 8 に示す。脳脊髄液の $\mathrm{T}_{2}$ 值におい て特に誤差が大きい結果となった。

\section{4. 考 察}

\section{4-1 従来法との $\mathrm{T}_{1} \cdot \mathrm{T}_{2}$ 值の比較}

3-1 より， $\mathrm{T}_{1}$ 值に関しては従来法による計測值と synthetic MRIの算出值の間に相関関係があり， synthetic MRIの算出する $T_{1}$ 值は正確に算出されている といえる。これは四つの saturation delays により，縦 磁化の回復を十分に推定できているためである。一 方, $\mathrm{T}_{2}$ 值の算出では誤差がみられた。これは 2 種類 の TEより $\mathrm{T}_{2}$ 緩和曲線を推定しているために測定点 が少ないこと，2nd TE が $100 \mathrm{~ms}$ と短いためだと考え られ, 推定される $\mathrm{T}_{2}$ 緩和曲線は $\mathrm{T}_{2}$ 值の長い領域にお いて誤差が大きくなる傾向にある. 


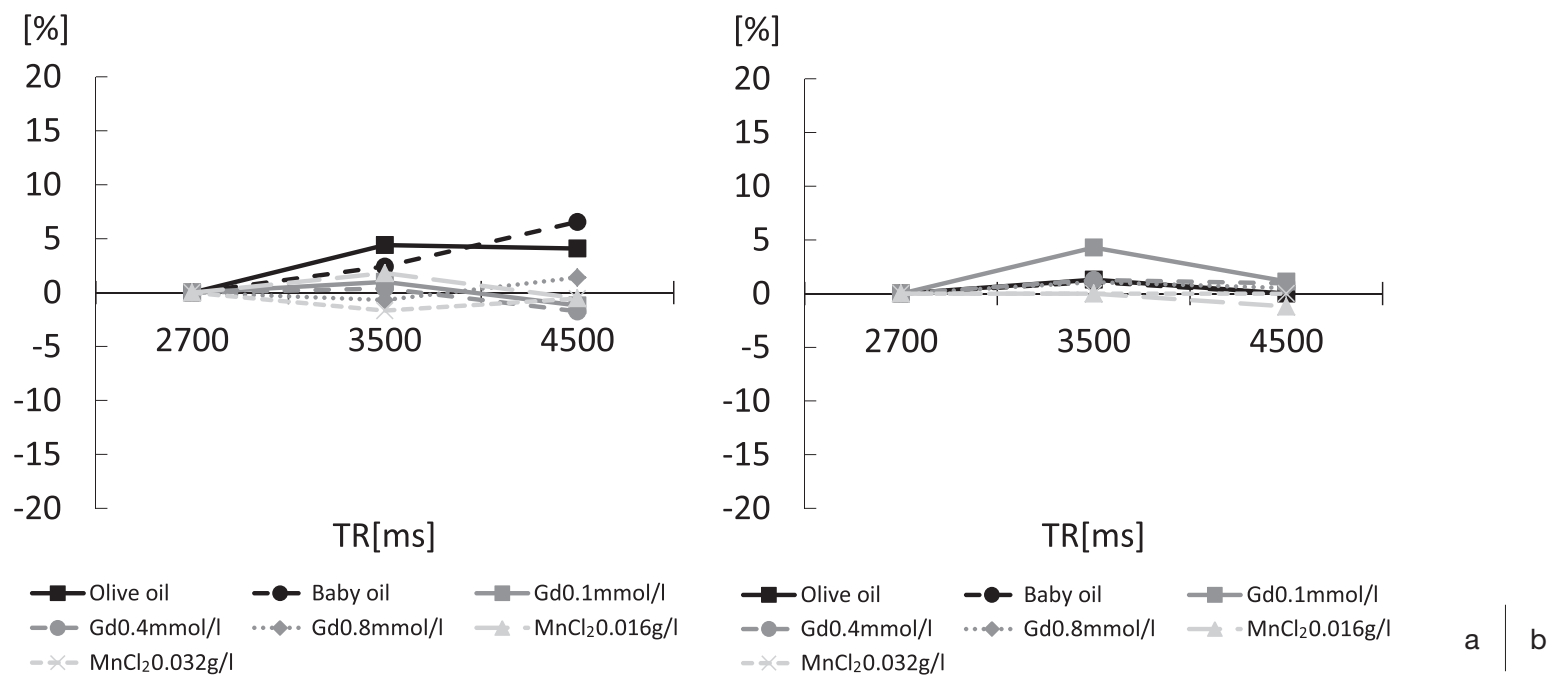

Fig. 6 The rate of change for $T_{1} \cdot T_{2}$ value by changing the TR.

(a) The rate of change for $T_{1}$ value

(b) The rate of change for $T_{2}$ value
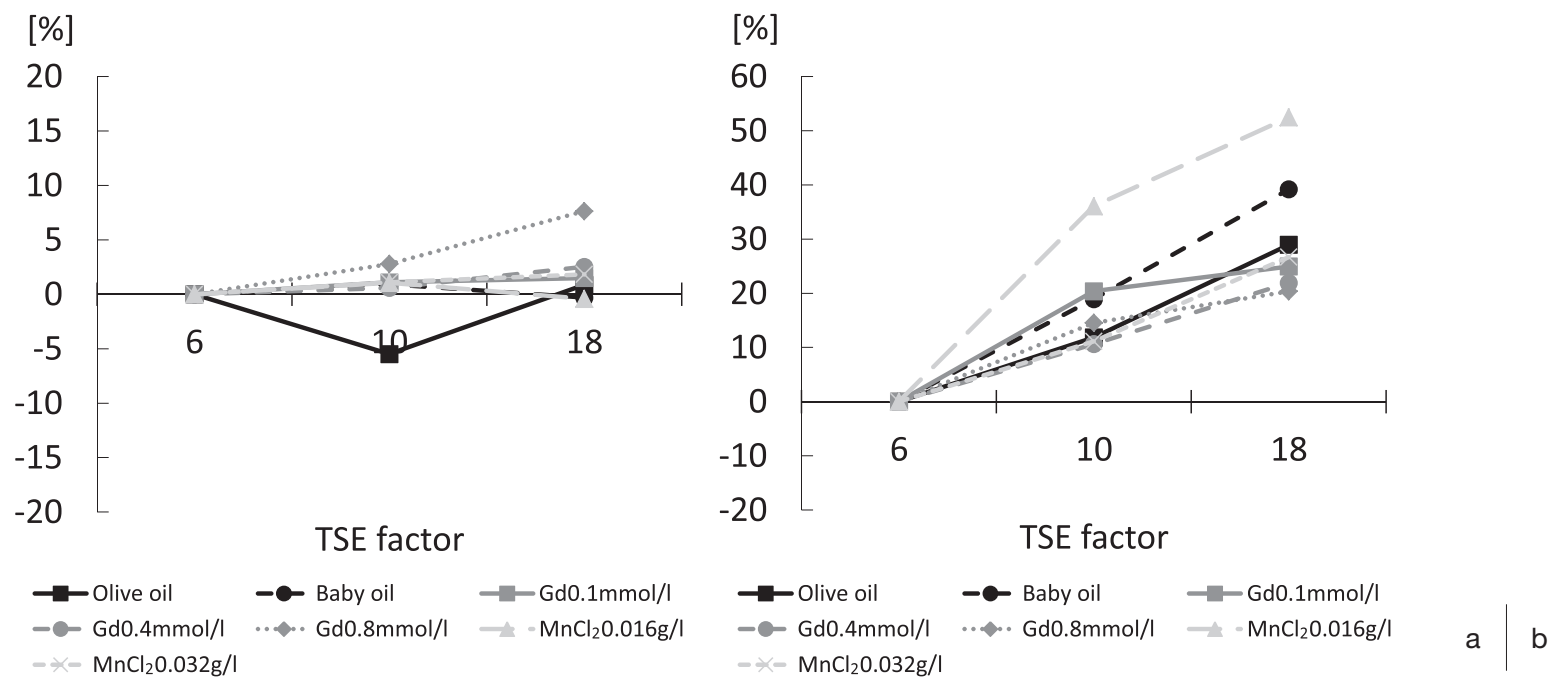

Fig. 7 The rate of change for $T_{1} \cdot T_{2}$ value by changing the TSE factor.

(a) The rate of change for $T_{1}$ value

(b) The rate of change for $T_{2}$ value
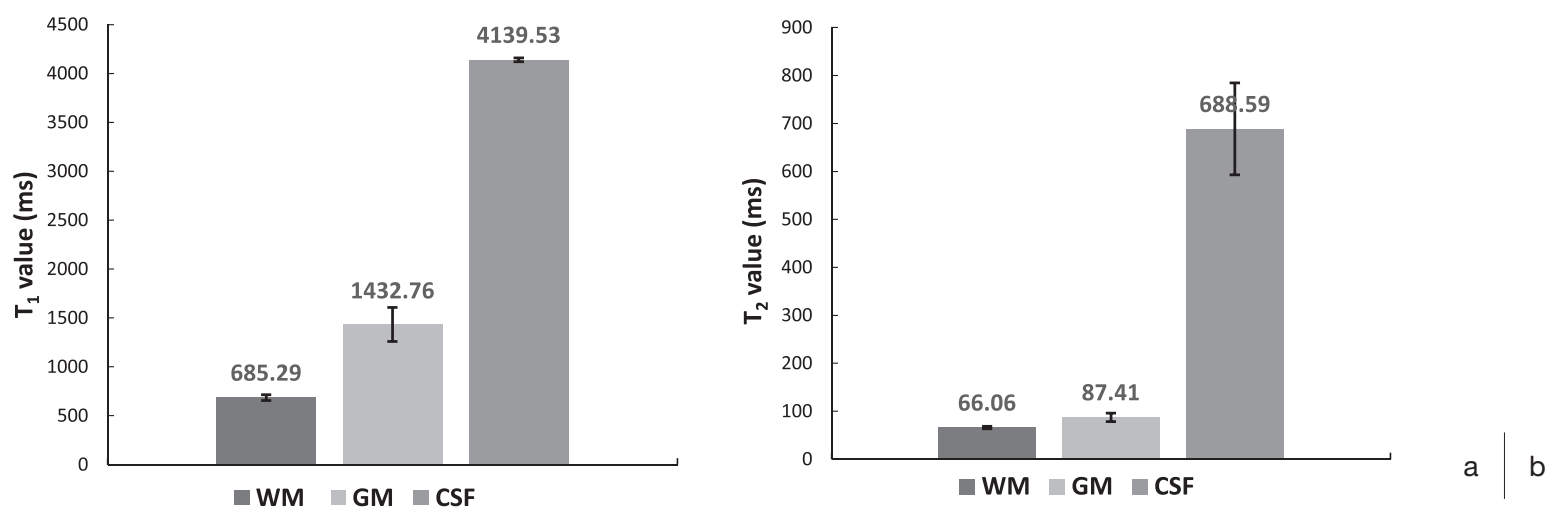

Fig. $8 \mathrm{~T}_{1} \cdot \mathrm{T}_{2}$ value of volunteer study.

(a) Average $T_{1}$ value and the standard deviation (SD) from Fig. 2

(b) Average $T_{2}$ value and the SD from Fig. 2 


\section{4-2 撮像パラメータを変化させた際の $T_{1} \cdot T_{2}$ 値への 影響}

3-2 より，算出される $\mathrm{T}_{1}$ 值に関して撮像パラメータ が及ぼす影響は小さいといえる。一方， $\mathrm{T}_{2}$ 值は $1 \mathrm{st}$ TE，2nd TE，TSE factor の影響を受ける結果となっ た，金澤らによると，2 エコーデータフィッティング による $\mathrm{T}_{2}$ 值測定において echo train length (ETL)を 増加しても mixed シーケンスとの差はなく, むしろ第 1 および第 2 エコーの実効 TE の影響が大きいと報告 されている8). しかし, synthetic MRIでは設定した 1st TE と act TEが一致していない場合が存在するこ とから，1st TE は設定值よりも 2nd TE と TSE factorによる影響を受けた実効 TE となっており，TSE factor も算出する $\mathrm{T}_{2}$ 值に影響を及ぼしている.

\section{4-3 ボランティアの $\mathrm{T}_{1} \cdot \mathrm{T}_{2}$ 值}

先行研究より，3.0 Tに扮ける白質の $\mathrm{T}_{1}$ 值は 791$1080 \mathrm{~ms} ， \mathrm{~T}_{2}$ 值は 70-110 ms 程度であり，灰白質にお いての $\mathrm{T}_{1}$ 值は 1331-1820 ms, $\mathrm{T}_{2}$ 值は 80-100 ms 程 度，脳脊髄液の $\mathrm{T}_{1}$ 值は 3817-4163 ms， $\mathrm{T}_{2}$ 值は 1442 $\mathrm{ms}$ 程度と報告されている ${ }^{9 \sim 11)}$. 3-3 より，本検討にお いて $\mathrm{T}_{1}$ 值に関しては正確に算出できているといえ る， $\mathrm{T}_{2}$ 值は脳実質では正確に算出できているが，脳
脊髄液において既知の值とかけ離れている結果となっ た。これは1st TE と2nd TEの実効 TE が脳実質に は適合しているが, 脳脊髄液のような $\mathrm{T}_{2}$ 值の長い物 質には不適合なためと考えられる。

\section{4-4 リミテーション}

本研究では 1st TE，2nd TE，TR，TSE factor を変 化させた際の synthetic MRI が算出する $\mathrm{T}_{1} \cdot \mathrm{T}_{2}$ 值に 着目し、ファントムを用いた検討を行った。この結果 から $\mathrm{T}_{2}$ 值の変動が大きいといえるが，真值を正確に 定量するための最適な条件を見つけられたわけではな い. また，ボランティア撮像では PHILIPS 推奨条件 を参考に正常ボランティアの脳実質および脳脊髄液の 測定を行ったが，臨床患者での検討は行っていない． $\mathrm{T}_{2}$ 值に誤差があったことから $\mathrm{T}_{2}$ 延長病変を有する患 者や髄鞘化の進んでいない新生児での検討は今後必要 と考えられる.

\section{5. 結 語}

本検討から synthetic MRI が算出する緩和值 $\left(\mathrm{T}_{1}\right.$. $\mathrm{T}_{2}$ 值)は撮像パラメータの影響を受けており，撮像時 には適切なパラメー夕設定が必要と考えられる。

\section{参考文献}

1) Andica C, Hagiwara A, Nakazawa M, et al. The advantage of synthetic MRI for the visualization of early white matter change in an infant with Sturge-Weber syndrome. Magn Reson Med Sci 2016; 15(4): 347-348.

2) Hagiwara A, Nakazawa M, Andica C, et al. Dural enhancement in a patient with Sturge-Weber syndrome revealed by double inversion recovery contrast using synthetic MRI. Magn Reson Med Sci 2016; 15(2): 151-152.

3) Hagiwara A, Hori M, Suzuki M, et al. Contrast-enhanced synthetic MRI for the detection of brain metastases. Acta Radiol Open 2016. doi:10.1177/2058460115626757.

4) In den Kleef JJ, Cuppen JJ. RLSQ: T1, T2, and rho calculations, combining ratios and least squares. Magn Reson Med 1987; 5 (6): 513-524.

5) Andersen C, Jensen FT. Precision, accuracy, and image plane uniformity in NMR relaxation time imaging on a $1.5 \mathrm{~T}$ wholebody MR imaging system. Magn Reson Imaging 1994; 12(5): 775-784.
6) Warntjes JB, Dahlqvist O, Lundberg P. Novel method for rapid, simultaneous $\mathrm{T} 1, \mathrm{~T} 2 *$, and proton density quantification. Magn Reson Med 2007; 57(3): 528-537.

7) Warntjes JB, Leinhard OD, West J, et al. Rapid magnetic resonance quantification on the brain: optimization for clinical usage. Magn Reson Med 2008; 60(2): 320-329.

8）金澤裕樹, 宮地利明，八木絢子, 他. 高速スピンエコー法 を用いた $\mathrm{T}_{1} \cdot \mathrm{T}_{2}$ 同時計測 MRI. 医用画像情報会誌 2010; 27(4): 111-115.

9) Wansapura JP, Holland SK, Dunn RS, et al. NMR relaxation times in the human brain at 3.0 tesla. J Magn Reson Imaging 1999; 9(4): 531-538.

10) Chen L, Bernstein M, Huston J, et al. Measurements of $T 1$ relaxation times at 3.0T: implications for clinical MRA. Proc Intl Soc Mag Reson Med 2001; 9: 1391.

11) Maclntosh BJ, Graham SJ. Magnetic resonance imaging to visualize stroke and characterize stroke recovery: a review. Front Neurol 2013. doi:10.3389/fneur.2013.00060. 